УДК 656.222.3

DOI: $10.15587 / 2313-8416.2014 .29269$

\title{
УДОСКОНАЛЕННЯ ТЕХНОЛОГІЇ ФОРМУВАННЯ ПОЇЗДІВ НА СТАНЦІЯХ ЗАЛІЗНИЧНИХ ВУЗЛІВ
}

\author{
(С) Ю. В. Рибалка, Г. М. Сіконенко
}

\begin{abstract}
Для удосконалення оперативного планування розвезення місцевого вантажу між станціями залізничного вузла в умовах раціонального використання транспортних засобів запропоновано застосовувати гнучкі підходи до формування передаточних поїздів на станціях залізничних вузлів з урахуванням добової нерівномірності. Зменшити простої составів у парках відправлення можливо за рахунок багатопрофільного використання поїзних локомотивів та раціоналізації маневрової роботи.

Ключові слова: станція, вузол, локомотив, вагон, планування, накопичення, формування, транспорт, залізниця, нерівномірність.
\end{abstract}

Usage a flexible approach to the formation of transmission trains at the stations of railway junctions taking into account the daily irregularity was proposed to improve operational planning of transporting of the local cargo between stations in a railway junction under the conditions of the improvement of the usage of vehicles. It is possible to reduce downtime in the parks of dispatch due to the multidiscipline usage of train locomotives and rationalization of maneuvers.

Keywords: station, junction, locomotive, wagon, planning, accumulation, formation, transport, railway, irregularity.

\section{1. Вступ}

Зміни, що постійно відбуваються на транспортному ринку, в характері й обсязі потреб у перевезеннях спонукають залізницю пристосовуватися до мінливих умов шляхом впровадження нових технологій 3 метою зменшення витрат i збільшення продуктивності. Усі галузі залізничного господарства повинні вийти на такий рівень, щоб залізниця могла пропонувати споживачам транспортне обслуговування, яке за якістю і цінами витримує конкуренцію з боку інших видів транспорту і здатне залучити на нових клієнтів. Це повною мірою стосується залізничну інфраструктуру, зокрема i залізничні вузли.

Залізничні об'єкти, в тому числі і залізничні вузли, являють собою складні системи, а процеси, що на них відбуваються в більшості випадків протикають таким чином, що не можуть бути описані простими залежностями. Насамперед це впливає на прийняття рішення оперативними працівниками, які знаходять їх або інтуїтивно, або за допомогою найпростіших математичних розрахунків, що на забезпечує прийняття оптимального рішення.

Графік руху та план формування дають загальний напрямок, загальний хід виконання того чи іншого експлуатаційного процесу, однак в реальних умовах при здійсненні їх виникають багато чисельні випадкові явища. Наприклад, процес накопичення відбувається при випадковому підході груп вагонів. 3 кожним поїздом підходять групи вагонів, що відрізняються від тих, які прибували у минулу або прибудуть у майбутню добу. Не може бути такого положення, щоб кожне підприємство відправляло однакову кількість вагонів у суворо визначений час, щоб ці вагони кожен день попадали на всьому шляху прямування в одні і ті ж поїзди та інш.

Великий вклад в розвиток методів планування перевезень по залізницях внесли доктора наук
О. П. Абрамов, О. О. Бакаєв, М. М. Барков, І. В. Белов, В. А. Дмитрієв, А. Г. Захаров, Б. І. Шафіркін, та ін. Теоретичні питання інтенсифікації роботи станцій та напрямків освячені у працях Є. В. Архангельського, Д. Д. Ашукіна, В. К. Буянової, Б. Е. Пейсахзона, М. Д. Іловайського, М. Д. Крюкова, Б. М. Максимовича, В. І. Некрашевича, О. С. Пермінова, К. К. Тихонова, І. В. Харлановича, А. Д. Чернюгова та ін. Проблеми нерівномірності в експлуатаційній роботі залізниць детально досліджені в роботах А. К. Угрюмова, Ю. В. Дьякова, Д. Ю. Левина, В. А. Кудрявцева, В. И. Некрашевича, А. Ф. Бородіна та В. И. Бодюла.

\section{2. Аналіз літературних даних та постановки проблеми}

Питання удосконалення формування поїздів на залізничних станціях і у закордонній періодиці. Так у [1] пропонують методи розрахунку вагоно-годин знаходження вагонів на сортувальних станціях та шляхи скорочення часу знаходження вагонів при частковій переробці вагонопотоку на допоміжних сортувальних станціях. На Британських залізницях існує проблема підвищення пропускної спромогності ліній у залізничних вузлах [2]. Для досягнення поставленої мети запропоновано планувати відправлення поїздів у залізничному вузлі при використанні новітніх комп'ютерних технологій, а саме систем самонавчання на основі мезоскопічної імітаційної моделі з урахуванням безвідмовної роботи інфраструктури.

Екстремальні затримки можуть привести до великих штрафів для залізничного компанії, а також незадоволених клієнтів. Состави поїздів, що прибувають на станцію $є$ величиною динамічною. Тому, у дослідженні [3] запропоновано застосування алгоритмів мурашиної колонії для планування роботи залізничного вузла за допомогою імітації 
реальних переходу в залізничній мережі Великобританії за зразком поведінки мурах у колоніях. Плануванню роботи у залізничних вузлах присвячене і дослідження [4]. Вирішити проблему залізничного вузла з високим коефіцієнтом вико ристання пропускної спроможності можливо завдяки плануванню в гнучких системах на основі мережі Петрі (ТПС). Спочатку для визначення поведінки математичної моделі використовують методи комбінаторної оптимізації, а потім спрощують модель за допомогою використання мережі Петрі. У роботі [5] показано, що використання звичайних та простих методів для планування формування поїздів та пропуску в межах залізничних вузлів або неефективно, або потребує значних обчислювальних потужностей. Тому, запропоновано планування роботи проводити за допомогою евристичних методів, а саме використовувати генетичні алгоритми. Однак, дані публікації не висвітлюють скорочення простоїв транспортних засобів на технічних станціях залізничних вузлів з урахуванням витрат на проведення маневрової та поїзної роботи.

\section{3. Мета та задачі дослідження}

Метою дослідження $\epsilon$ удосконалення оперативного планування розвезення місцевого вантажу між станціями залізничного вузла в умовах покращення використання транспортних засобів та забезпечення логістичних основ управління між всіма суб'єктами перевезення. Реалізація цієї мети потребує постановку та вирішення таких основних задач:

- аналіз існуючої технології поїздоут-ворення на станціях залізничного вузла 3 дослідженням вхідних поїздопотоків;

- формалізація задачі визначення формування передаточних поїздів 3 урахуванням багатопрофільного використання локомотивів.

4. Результати результатів дослідження формування передаточних поїздів на станціях залізничних вузлів

Технічне обладнання станцій значно впли-ває на тривалість обробки поїздів та вагонів, собівартість переробки, а також на безпеку руху поїздів та маневрової роботи. Саме скорочення часу знаходження вагонів на станціях залізничних вузлів істотно сприяє прискоренню доставки вантажів та задоволенню потреб в перевезеннях зацікавленої клієнтури. У відповідності до звітності Укрзалізниці середній простій при кожній переробці складає більш 8 годин.

Як відомо, теорія керування перевезеннями на залізницях має імовірнісну основу. Наприклад, інформація про реальний підхід вантажних поїздів до сортувальної станції, структурі вагонопотоку стає відомою лише на кілька годин уперед. У більшості випадків ці поїзди не узгоджуються 3 нитками графіка. У підсумку частина ниток графіка не використовується.

Час знаходження вагонів на сортувальних станціях в значному ступені залежить від простою вагонів при накопиченні составів та наявності вантажів на підходах. Питанням теорії процесу накопичення вагонів на сортувальних станціях приділяється велика увага.

В методиці К.А. Бернгарда [6] величина оптимальне число поїздів у вузлі $n_{\text {on }}$ визначається шляхом порівняння варіантів по витратам на накопичення, маневрову роботу i переміщення передаточних поїздів. Однак, розрахунки не враховуються витрати на затримки поїздів на підходах до сортувальної станції i на простої рухомого складу в очікуванні виконання опера-цій, зокрема очікуванні поїзних локомотивів. Витрати ці можуть складати в окремих випадках 15-20\% від загальної суми витрат.

В залізничних вузлах окремі дільниці, сортувальні і вантажні станції технологічно тісно пов язані між собою і обслуговуються одними і тими ж або маневровими або передаточним локомотивами. Тому оптимальне рішення необ-хідно знаходити для всієї системи, що розглядається в цілому 3 врахуванням не тільки витрат по руху передаточних поїздів і простою місцевих вагонів під операціями, але i витрат на сортувальних, вантажних і інших станціях вузла і дільницях, що характеризуються в теперішній час великою нерівномірністю розмірів руху [7].

Коли відправлення вантажів відбувається невеликим партіями 3 високим коефіцієнтом нерівномірності розрахункові витрати, за якими обирається оптимальний варіант плану формування та відправлення передаточних поїздів у вузлі, повинні враховувати додаткові витрати пов'язані 3 нерівномірним підводом поїздів до сортувальних станцій.

При плануванні поїздоутворення необхідно враховувати похибку від неточності прогнозу. Така похибка у грошовому вимірі буде розраховуватися за формулою [8]

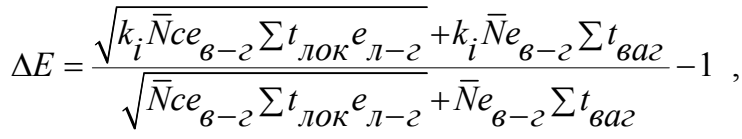

де $k_{i}$ - коефіцієнт нерівномірності перевезень; $\bar{N}-$ середній вагонопотік, ваг; $c$ - параметр накопичення, год; $e_{6-2}-$ вартість однієї вагоногодини, грн; $e_{л-2}-$ вартість однієї локомотивогодини, грн; $\sum t_{\text {ваг }}$ - змінна частини витрат вагоногодин на переробку вагонів та прямування в поїздах,

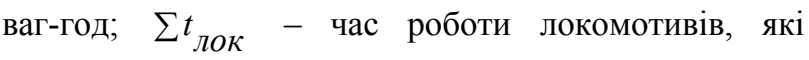
обслуговують поїзди даної категорії, що приходиться на один поїзд, лок-год.

Планування поїздоутворення пропонується проводити за умови мінімізації часу знаходження вагонів та локомотивів на станціях вузла та паливноенергетичних ресурсів, пов'язаних з маневровою та поїзною роботою. Запропоновану технологію удосконалення можливо описати цільовою функцією

$$
E_{\text {міси }}=E_{\text {сорт }}+E_{\text {лок }}+E_{\text {ман }}+E_{\text {вант }}+\Delta E \rightarrow \min E_{\text {міси }} \text {. }
$$


При наступних обмеженнях

$$
\left\{\begin{array}{l}
N_{n е р} \succ 0 ; \\
m_{c е p} \succ 0 ; \\
t_{з н} \leq T_{н о р} \\
t_{л б} \leq 8
\end{array}\right.
$$

де $E_{\text {сорт }}-$ вартість знаходження вагонів на сортувальних станціях (формування i розформування, накопичення, подавання і забирання та інш.,), грн.; $E_{\text {лок }}-$ вартість роботи вивізних локомотивів, грн.; $E_{\text {ман }}-$ вартість роботи маневрових локомотивів при розформуванні i формуванні составів, подаванні та забиранні вагонів, грн.; $E_{\text {вант }}-$ вартість знаходження вагонів на вантажних фронтах станцій вузла під обслуговуванням, грн.; $t_{\text {зн }}-$ час знаходження вагонів на станції, год; $T_{\text {нор }}-$ нормативний час знаходження вагонів на станції, год; $N_{\text {nер }}$ - кількість передаточних поїздів, які очікують обслуговування; $m_{\text {сер }}$ - середня кількість вагонів під різними технологічними операціями.

У явному вигляді складові цільової функції мають вигляд

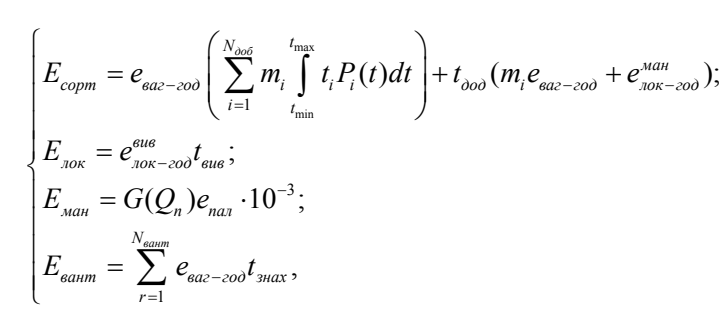

де $e_{\text {ваг-год }}, e_{\text {лок-год }}^{\text {вив }}, e_{\text {лок-год }}^{\text {ман }}, e_{\text {пал }}-$ відповідно вартість однієї години простою вагону, роботи вивізного та маневрового локомотива, палива, грн./год; $m_{i}-$ состав поїзда, ваг; $t_{i}$ - час перебування в $i$-му стані, год; $P_{i}(t)$ - ймовірність знаходження вагону в $i$-му стані; $t_{\text {дод }}$ - додатковий міжопераційний простій, год; $t_{\text {вив }}$ - час роботи вивізного локомотива при передачі вагонів по станціях вузла, год; $G\left(Q_{n}\right)$ - залежність витрат палива від ваги состава, кг; $t_{\text {знах }}$ - час знаходження на вантажних фронтах з урахуванням очікування подавання - забирання, год.

Визначення $\Delta E$ наведено у формулі (1).

Для визначення економічної доцільності впровадження запропонованих методів удосконалення технології роботи вивізних локомотивів та оперативного планування розвезення вантажу у вузлі порівняні показники роботи до впровадження та після із урахуванням рекомендацій, викладених у [9].

Середня кількість вагонів у составі вивізного поїзда визначена на основі обробки статичних даних за максимальний та мінімальний місяці. Результати розрахунків наведено на рис. 1.

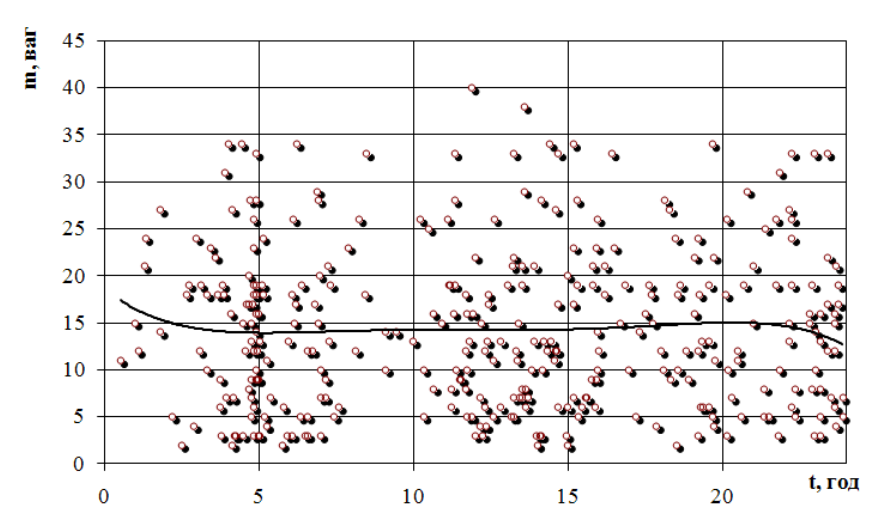

$y=-4 E-05 x^{5}+0,0022 x^{4}-0,0503 x^{3}+0,5405 x^{2}-2,6349 x+18,625$

Рис. 1. Аналіз составу вивізного поїзда, що курсує у залізничному вузлі

При цьому бачимо, що состав вивізного поїзду коливається в межах від 3 до 41 вагону, а математичне очікування $M[x]$ складає 19 вагонів.

Вартість очікування вагонами обслуговування визначається, виходячи 3 імовірнісно-залежної тривалості виконання та очікування відправлення на станції вузла, повернення з під'їзної колії на станцію, операцій при прибутті на станцію, операцій по відправленню зі станції вузла, прийомо - здавальних операцій на під’їних коліях та місцях загального користування, розформування, подачі та розставлення, вивантаження, навантаження, переставлення, подавання-забирання, накопичення вагонів на станційних коліях та середньої кількості вагонів, що знаходяться в очікуванні різних технологічних операцій.

Час на очікування слідування та після повернення 3 вантажних фронтів на станцію, операцій $з$ прибуття вагонів на станцію, операцій по відправленню зі станції, прийомо - здавальних операцій на вантажних фронтах, розформування, подачі та розставлення, вивантаження, навантаження, переставлення, збирання-убирання, накопичення визначаються згідно законів розподілення.

Час на проведення інших технологічних операцій приймається згідно з середніми місячними технічними нормами, що видають для кожної станції.

На основі моделювання отримано поверхню відгуку, що дозволить визначати середню масу передаточного поїзду, час простою у кожному технологічному стані та загальні витрати 3 урахуванням витрат маневрових та вивізних локомотивів при багатопрофільному їх використанні.

На рис. 2. наведено приклад залежності загальних експлуатаційних витрат від вагової категорії передаточного поїзду та часу знаходження вагонів на станціях залізничного вузла.

При оперативному плануванні треба мати на увазі, що додатковий простій окремих составів поїздів в парках відправлення викликаються несвоєчасним підводом локомотивів і це приводить до збільшення часу доставки вантажу, уповільнення обороту вагонів. Вказані витрати можна значною мірою скоротити при впровадженні багатопрофільного використання поїзних 
локомотивів [10] та за рахунок комплексного підходу до вирішення задачі оперативного планування роботи локомотивів вантажного руху. Ці розрахунки повинні базуватися на формуванні єдиної моделі залізниці та інтегрованої бази даних при використанні локальних розрахункових мереж.

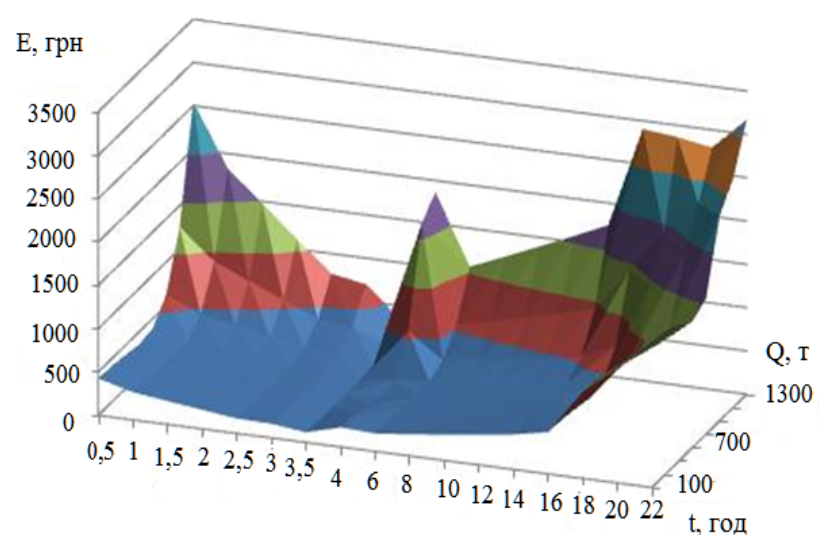

Рис. 2. Приклад залежності загальних

експлуатаційних витрат від вагової категорії передаточного поїзду та часу знаходження вагонів на станціях залізничного вузла

\section{5. Обговорення результатів дослідження} формування передаточних поїздів на станціях залізничних вузлів

В умовах автоматизації створюються посилання для такого комплексного підходу до вирішення задачі оперативного планування роботи локомотивів вантажного руху.

Перехід до оптимального керування передбачається здійснити шляхом зміни технологічних процесів роботи персоналу станції, що досягається застосуванням нових інформаційних технологій i підтримуючих їх програмних алгоритмів. У цей час іде процес виділення в лінійних районах сортувальних станцій для передачі їм максимально можливого обсягу сортувальної роботи з метою концентрації сортувальної роботи.

Вирішення задачі формування передаточних поїздів на станціях залізничних вузлів за допомогою запропонованої моделі дозволить значно скоротити час знаходження вагонів на станціях залізничних вузлів; зменшити витрати на маневрову та поїзну роботу за рахунок багатопрофільного використання локомотивів та скорочення палива і електроенергії при раціоналізації планування відправлення поїздів на станції вузла; скоротити непродуктивні між операційні простої вагонів.

Дана робота $є$ продовженням робіт зі раціоналізації часу знаходження вагонів на станціях залізничних вузлів та потребує подальших досліджень.

\section{6. Висновки}

На підставі проведених досліджень можна зробити такі висновки:

1. Експлуатаційні витрати, пов'язані з просто$€ м$ та переробкою вагонів, в тому числі і місцевих, на сортувальних та вантажних станціях вузла можли- во скоротити за рахунок удосконалення оперативного планування роботи, що дозволить поліпшити показники роботи не тільки залізничного транспорту, але й інших при їх взаємодії у транспортних вузлах.

2. Внутрішньодобові коливання вагонопотоків у вузлах впливають на термін планування експлуатаційної роботи. Розраховані на тривалий період плани не $\epsilon$ фактично оптимальним на протязі значної частини цього періоду. Тому, запропоновано обирати найбільш раціональний варіант плану відправлення поїздів на станції вузла у відповідності до величини вагонопотоку.

3. В результаті моделювання отримано рекомендації, що дадуть змогу зменшити час доставки вантажів вантажоодержувачу, дотримуватися графіку курсування поїздів, скоротити час обслуговування на технічних та вантажних станціях вузлів при наявності ниток графіку для вже сформованих поїздів та інформації про наявність локомотивів і локомотивних бригад.

\section{Література}

1. Xie, J. B. Wagon Hours Saved by Transferring Wagons without Sorting Operations at Technical Station [Text] / J. B. Xie, L. Gao, J. Zhang // Applied Mechanics and Materials. - 2011. - Vol. 97-98. - P. 498-502. doi: 10.4028/www.scientific.net/amm.97-98.498

2. Liu, R. Challenging established rules for train control through a fault tolerance approach: applications at a classic railway junction [Text] / R. Liu, A. Whiteing, A. Koh // Proceedings of the Institution of Mechanical Engineers, Part F, 2013. - Vol. 227, Issue 6. - P. 685-692. doi: $10.1177 / 0954409713496988$

3. Eaton, J. Dynamic railway junction rescheduling using population based ant colony optimization [Text] / J. Eaton, Sh. Yang // 14th UK Workshop on Computational Intelligence (UKCI), 2014. doi: 10.1109/ukci.2014.6930174

4. Hammadi, S. Optimization of Traffic at a Railway Junction: Scheduling Approaches Based on Timed Petri Nets [Text] / S. Hammadi, M. Ksouri // Multimodal Transport Systems, 2013. - P. 199-251. doi: 10.1002/ 9781118577202.ch5

5. Ho, T. Railway junction conflict resolution by genetic algorithm [Text] / T. K. Ho, T. H. Yeung // Electronics Letters. - 2010. - Vol. 36, Issue 8. - P. 771-772. doi: 10.1049/el:20000570

6. Бернгард, К. А. Нормирования размеров движения передаточных поездов в железнодорожных узлах [Текст] / К. А. Бернгард // Техника железных дорог. 1953. - № 4. - С. 21-25.

7. Первозванский, А. А. Математические модели в управлении производством. [Текст] / А. А. Первозванский. - М.: Наука, 1973. - 615 с.

8. Габасов, Р. Ф. Методы оптимизации [Текст] / Р. Ф. Габасов, Ф. М. Кириллова. - Минск: БГУ, 1981. $350 \mathrm{c}$.

9. Балака, Є. І. Оцінка економічної доцільності інвестицій в інноваційні проекти на транспорті [Текст] : навч. пос. / Є. І. Балака, О. І. Зоріна, Н. М. Колесникова, I. М. Писаревський. - Харків: УкрДАЗТ, 2005. - 210 с.

10. Сигорский, В. П. Математический аппарат инженера [Текст] / В. П. Сигорский. - К.: Техника, 1975. - 768 c.

\section{References}

1. Xie, J. B., Gao, L., Zhang, J. (2011). Wagon Hours Saved by Transferring Wagons without Sorting Operations at 
Technical Station. Applied Mechanics and Materials, 97-98, 498-502. doi: 10.4028/www.scientific.net/amm.97-98.498

2. Liu, R., Whiteing, A., Koh, A. (2013). Challenging established rules for train control through a fault tolerance approach: applications at a classic railway junction. Proceedings of the Institution of Mechanical Engineers, Part F, 227 (6), 685-692. doi: 10.1177/0954409713496988

3. Eaton, J., Yang, Sh. (2014). Dynamic railway junction rescheduling using population based ant colony optimization. 14th UK Workshop on Computational Intelligence (UKCI). doi: 10.1109/ukci.2014.6930174

4. Hammadi, S., Ksouri, M. (2013). Optimization of Traffic at a Railway Junction: Scheduling Approaches Based on Timed Petri Nets. Multimodal Transport Systems, 199-251. doi: 10.1002/9781118577202.ch5

5. Ho, T. K., Yeung, T. H. (2010). Railway junction conflict resolution by genetic algorithm. Electronics Let- ters, 36 (8), 771-772. . doi: 10.1049/el:20000570

6. Bernhard, K. A. (1953). Normyrovanyya razmerov dvyzhenyya peredatochnykh poezdov $\mathrm{v}$ zheleznodorozhnykh uzlakh. Tekhnyka zheleznykh doroh, 4, 21-25.

7. Pervozvanskyy, A. A. (1973). Matematycheskye modely v upravlenyy proyzvodstvom. Nauka, 615.

8. Habasov, R. F., Kyryllova, F. M. (1981). Metody optymyzatsyy. BHU, 350.

9. Balaka, Ye. I., Zorina, O. I., Kolesnykova, N. M., Pysarevs'kyy, I. M. (2005). Otsinka ekonomichnoyi dotsil'nosti investytsiy $\mathrm{v}$ innovatsiyni proekty na transporti. UkrDAZ, 210.

10. Syhorskyy, V. (1975). Matematycheskyy apparat inzhenera. Transport, 768.

Рекомендовано до публікаиії д-р техн. наук Огар О. М. Дата надходження рукопису 31.10.2014

Рибалка Юлія Віталіївна, студент, кафедра управління експлуатаційною роботою, Українська державна академія залізничного транспорту, пл. Фейєрбаха, 7, м. Харків, 61050

E-mail: yulya.rybalka.92@mail.ru,

Сіконенко Григорій Михайлович, кандидат технічних наук, доцент, кафедра управління експлуатаційною роботою, Українська державна академія залізничного транспорту, пл. Фейєрбаха, 7 , м. Харків, 61050

E-mail: gregsik79@gmail.com

UDC: $\mathbf{6 2 1 . 3 7 3 . 8 2 6}$

DOI: $10.15587 / 2313-8416.2014 .29615$

\section{USING SPECTROSCOPY OF THE NEAR-INFRARED TECHNIQUES TO DETECTION THE GAS}

\section{(C) Haider Ali Muse}

Near-infrared spectroscopy is a spectroscopic method that uses the near-infrared region of the electromagnetic spectrum. In this paper we will explain the methane detector by using near-infrared radiation with different wavelengths ranges $(800 \mathrm{~nm} \lambda$ to $950 \mathrm{~nm} \lambda)$. The results, that have been obtained, had the greatest value within the wavelength $850 \lambda \mathrm{nm}$.

Keyword: diode lasers, near-infrared, absorbs, methane, detection , spectroscopic.

Ближня інфрачервона спектроскопія $е$ спектроскопічним методом, який використовує ближню інфрачервону область електромагнітного спектра. У иій статті ми покажемо, як виявити газ метану за допомогою ближньої інфрачервоної радіачії з різним діапазоном довжин хвиль (від 800 нмд до 950

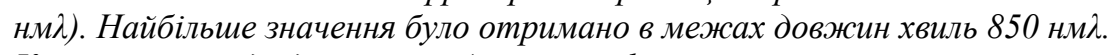

Ключові слова: діодні лазери, ближній інфрачервоний, поглинння метану, виявлення, спектроскопія.

\section{Introduction}

Due to the important role of spectroscopy of the laser and found immediate application in various fields, one of these fields is the detection and identification . In this research we will explain methane detection by using near-infrared. Methane is a chemical compound with the chemical formula $\mathrm{CH} 4$. It is the simplest alkane, the main component of natural gas, and probably the most abundant organic compound on earth [1]. Methane is the main component of coal mine gas and natural gas, and it is closely connected with the people's daily activities and life. Since methane gas is inflammable and explosive, it is important to accurately detect the concentration of methane gas. All this made us think to design of this device to detect methane using Near-infrared. Near- infrared spectroscopy (NIRS) is a spectroscopic method that uses the near-infrared region of the electromagnetic spectrum (from about $800 \mathrm{~nm}$ to $2500 \mathrm{~nm}$ ) [2]. Nearinfrared spectroscopy is one of the most common spectroscopic techniques used by organic and inorganic chemists. Simply, it is the absorption measurement of different IR frequencies by a sample positioned in the path of an IR beam. The main goal of IR spectroscopic analysis is to determine the chemical functional groups in the sample. Different functional groups absorb characteristic frequencies of IR radiation. Using various sampling accessories, IR spectrometers can accept a wide range of sample types such as gases, liquids, and solids. Thus, IR spectroscopy is an important and popular tool for structural elucidation and compound identification. 